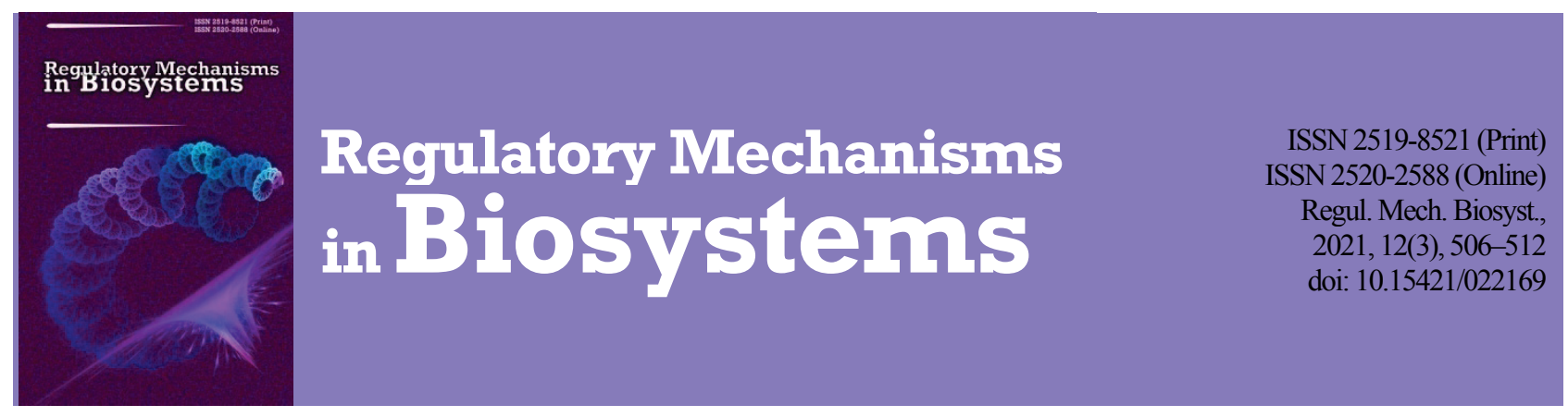

\title{
Induction of useful mutations in Triticum aestivum in the conditions of the radionuclide-contaminated alienation zone of the Chornobyl Power Plant
}

\author{
R. A. Yakymchuk*, V. F. Valyuk*, L. Y. Sobolenko**, S. I. Sorokina** \\ *Institute of Plant Physiology and Genetics, NAS of Ukraine, Kyiv, Ukraine \\ **Pavlo Tychyna Uman State Pedagogical University, Uman, Ukraine
}

Article info

Received 25.06.2021 Received in revised form 19.07.2021 Accepted 20.07.2021 Institute of Plant Physiology and Genetics of National Academy of Sciences of Ukraine, Vasyllkivska st., 31/17, Kyiv, 03022, Ukraine Tel.: +38-097-341-89-12. E-mail:

peoplenature16@gmail.com

Pavlo Tychyna Uman State Pedagogical University Sadovast., 2 ,

Uman, 20300, Ukraine. Tel.: + 38-096-303-59-82. E-mail: sobolenko@ukr.net

\begin{abstract}
Yakymchuk, R. A., Valyuk, V. F., Sobolenko, L. Y., \& Sorokina, S. I. (2021). Induction of useful mutations in Triticum aestivum in the conditions of the radionuclide-contaminated alienation zone of the Chornobyl Power Plant. Regulatory Mechanisms in Biosystems, 12(3), 506-512. doi:10.15421/022169
\end{abstract}

Induced mutagenesis opens great perspectives for radical genetic improvement of cultivated plants. Scientists seeking new sources and methodological approaches to improve the frequency and extend the range of mutations have drawn attention to the Zone of Alienation around the Chornobyl Nuclear Power Plant, where unique conditions of the influence of mutagenic factors have developed, and therefore needs to be studied for possible use of its territory in propagating parent material for selective breeding of wheat. Plants of winter wheat of Albatros Odesky and Zymoiarka varieties were grown within $10 \mathrm{~km}$ of the Chernobyl Plant, inside the Alienation Zone, in Chystohalivka, Kopachi and Yaniv villages of Chornobyl district of Kyiv Oblast. The exposure occurred in the dose of $7.2 \cdot 10^{-12}$ $50.0 \cdot 10^{-12} \mathrm{~A} / \mathrm{kg}$. As the control, we used the territory of the Research Institute of Physiology of Plants and Genetics of the Academy of Sciences of Ukraine (Hlevaha urbanized settlement of Vasylkivsky District of Kyiv Oblast), where the power of the exposure dose equaled $0.93 \cdot 10^{-12} \mathrm{~A} / \mathrm{kg}$. Frequency and spectrum of mutant forms were determined in $\mathrm{M}_{2}-\mathrm{M}_{3}$ generations according to the ratio of the number of families with mutagenic plants to studied $\mathrm{M}_{2}$ families. Among the observed mutations, we determined the share of the ones important for selective breeding. Chronic ionizing radiation throughout the vegetation period of winter wheat increased the level of noticeable mutations, the frequency of which exceeded the control parameters by 8.0-14.9 times. In the conditions of cultivation of winter wheat in the territory of Kopachi village, where the dose was the lowest, we recorded a high level of mutation variability which exceeded the control parameters by 8.0-9.2 times and was notably different from the frequency of mutations induced by radionuclide contamination of soil in the territories of Chystohalivka and Yaniv villages. The mutation range contained 12-20 types and depended on the density of soil contamination with radio nuclides, magnitude of exposure dose and genotype of plants. The predominant mutations were the ones related to the duration of vegetation period, length of the stem, morphology and awns of the ear. Among the detected mutations, the important selective ones accounted for $24.3-49.3 \%$, predominant being low height, intense growth and long cylindrical ear. Because beneficial agronomic traits are highly likely to be inherited in complex with mutations that reduce the productivity of winter wheat, efficiency of direct selection of mutant forms that are valuable for selective breeding is limited. Enlargement of genetic diversity of the initial selection material using the radionuclide-induced mutagenesis resulting from contamination creates the possibility of using it in cross breeding for the purpose of implementing selective breeding genetic programs of improving wheat varieties.

Keywords: ionizing radiation; induced mutagenesis; frequency of mutations; spectrum of mutations.

\section{Introduction}

Wheat is one of the planet's main grasses and plays the leading role in supply of food to humans. Because of its high ecological plasticity, it is distributed broadly (Beljaev et al., 2017; Bezpal'ko et al., 2020). Wheat fields in Ukraine occupy the largest share area of agricultural lands (Ryabchenko \& Nonhebel, 2016; Bhutta et al., 2019). However, mean annual rates of production of wheat grain were significantly behind the rates of increase in the global population, which according to the predictions will reach $9.1 \mathrm{~B}$ people by 2050 , while the need for food would increase by $70 \%$. According to the predictions made at the beginning of the century, at such rates of population growth, supporting the usual level of consumption of products would require doubling the yield of grain crops (Qaim, 2020; Senapati \& Semenov, 2020), and according to the assessments of the FAO, to satisfy basic food needs, humans must increase the yield by more than 0.5 tha annually over the next 10 years (Tadesse et al., 2019; Anders et al., 2021).

A promising way to increase the production of grain wheat is creating new high-yield varieties based on modern genetic inventions, which would be adapted to particular cultivation conditions. Generalization of the scientific studies and practical experiments confirms that contribution of variety to yield increment equals $50-60 \%$ of genetic potential of new varieties (Gubatov \& Delibaltova, 2020). Intense selective breeding oriented at increasing the productivity using the same donors of beneficial agronomic traits has led to significant impoverishment of the genetic fund of wheat (Venske et al., 2019), which in the recent decades has been promoting large-scale search for new sources of parent material using modern molecular-genetic, biochemical and technological approaches (Rasheed et al., 2018). This indicates the necessity to intensify the selection through the enlargement of genetic diversity and introduction of the latest achievements of genomics, proteomics and metabolic, genetically-modified technologies, tilling-technologies into the selective breeding (Jankowicz-Cieslak et al., 2017; Godwin et al., 2019; Zaidi et al., 2019; Qaim, 2020).

The studies performed over the recent years persuasively suggest that the use of induced mutagenesis opens great opportunities for the progress of selective breeding, radical genetic improvement of cultivated crops (Nazarenko et al., 2018). Therefore, the amount of varieties created using the method of experimental mutagenesis accounts for 31 thou. The greatest successes in the sphere of mutagenic selective breeding have been achieved in China, India, Japan, Russia, Sweden, Great Britain, Germany, 
France, Italy and the USA (Oladosu et al., 2016; Hernández-Muñoz et al., 2019). Vavylov (1966) considered that mutagenesis is one of the fundamental fields of genetics, which has definite advantages over some new but complex and laborious methods of genetic manipulation in cases of improving plant varieties. As of now, the method of experimental mutagenesis is used with different breeding purposes: obtaining macro and micro mutations of qualitative and quantitative traits and selection or direct practical implementation, overcoming of the non-crossing of distantly related forms, impact on crossing over of hybrids, inhibition of reaction of self-incompatibility in cross-fertilization plants, induction of polyploidy, etc. (Mir et al., 2020). Contemporary studies have aimed at improving effectiveness of induction of various original and selectively valuable mutants, and also creating principal sources of plants with high productivity, yield and resistibility to biotic and abiotic factors (Nazarenko, 2020). Notable achievements in scientific-practical direction have been made by specialists of the Institute of Physiology of Plants and Genetics of the Academy of Sciences of Ukraine, where there were created varieties of winter wheat which are being sown in Ukraine in an area of around $2 \mathrm{Mha}$, accounting to $30 \%$ of all fields in which this plant is cultivated (Morgun \& Rybalka, 2017).

Especially relevant now is the search for methodological approaches of increasing the frequency and enlarging the spectrum of mutations, opportunities of obtaining mutations having agricultural and important selection traits with high frequency (Yakymchuk \& Morgun, 2011). Therefore, scientists are currently actively seeking for mutagens that would cause a high level of controllable variability, significantly reduce the level of depression in plants and would be of lower cost price (Eyges, 2013). Along with laser rays, exposure to nitrogen ions, carbon, use of the conditions of the cosmic radiation in space (Khazaei et al., 2018; Yang et al., 2019; Mir et al., 2020; Mousseau \& Møller, 2020), there has arisen the issue of efficiency of using the complex of mutagenic factors of the environment, which have developed in technogenically contaminated territories. In this regard, an important stage of the research was the study of genetic consequences of radionuclide contamination in winter wheat in the $30 \mathrm{~km}$ Alienation Zone of the Chornobyl Power Plant (Morgun \& Yakymchuk, 2010; Yakymchuk, 2019). The study of the mutant lines grown in the conditions of environmental radionuclide contamination revealed the possibility of using them in selective breeding, and therefore resulted in development of highly productive winter-tolerant varieties Tsarivna, Lisova Pisnia, Romantyka, Vidrada on their bases (BurdeniukTarasevych et al., 2015). Therefore, the territory of anthropogenic radionuclide contamination in the Chornobyl Plant Alienation Zone may have unique conditions of mutagenic factors and requires study for the possibilities of its use during the development of parents for the selective breeding of winter wheat.

The objectives of the study were frequency and spectrum of mutations in Triticum aestivum L. in the conditions of chronic exposure of the plants to ionizing radiation in the Chornobyl Alienation Zone and efficiency of using the radionuclide-contaminated territory in induction of selection valuable mutations.

\section{Materials and methods}

To study the mutagenic activity of radionuclide contaminations in the Chornobyl Alienation Zone 30 years after the accident, we used Albatros Odesky and Zymoiarka varieties of winter wheat ( $T$. aestivum L.). The plants were grown within Chystohalivka village $(6 \mathrm{~km}$ from the Power Plant), Kopachi village (4 km from the Plant) and Yaniv village (3 $\mathrm{km}$ from the Plant) of Chomobyl District of Kyiv Oblast (Fig. 1). Depending on the radionuclide contamination, the exposure dose equaled 7.2 10 ${ }^{12}-50.0 \cdot 10^{-12} \mathrm{~A} / \mathrm{kg}$. As the control, we used the territory of the Research Institute of Physiology of Plants and Genetics of the NAS of Ukraine (Hlevaha urban-type settlement of Vasylkiv district of Kyiv Oblast), where the exposure dose was $0.93 \cdot 10^{-12} \mathrm{~A} / \mathrm{kg}$ and where the spontaneous level of mutation variability in winter wheat plants has been being studied over many years (Table 1).

Throughout the vegetation period, winter wheat plants were subjected to chronic radiation. The first generation of plants $\left(\mathrm{M}_{1}\right)$ was sown by mechanical broadcasting in polluted territories. Seeds were sown in the optimum period in the area in $5 \mathrm{~m}^{2}$ plots. In the phase of complete maturity, the plants were reaped and each ear was threshed individually. Plants of $\mathrm{M}_{2}$ and $\mathrm{M}_{3}$ generations were cultivated in the conditions of natural radiation fund (Hlevaha urban-type settlement of Vasylkiv district of Kyiv Oblast). They were grown distinctly in families, allowing them to manifest macro- and micro-mutations, which we correctly recorded. A family was considered to be a group of plants that grew from one ear. Families were sown manually in $1.5 \mathrm{~m}$-long rows with $15 \mathrm{~cm}$ distance between the rows. Mutations were considered to be only those altered traits that had been inherited in the subsequent generations. Different cases of mutations were considered the plants that were phenotypically distinct from the initial form within one family. Plants with altered traits were distinguished by accurate analysis of all families during the course of their main phases of growth and development. At the stage of ear formation, we were monitoring the rates of growth and tillering, specific changes in the stem and leaves, detecting plants with intense waxy layer and without waxy layer, including delayed and early massive ear formation, as compared to the standard families. Early matured forms were determined compared with the generally accepted standard of winter wheat variety Donska Napivkarlykova. Mutations according to morphological traits of the ear were monitored in the period spanning the blossom to ripening of the seeds.

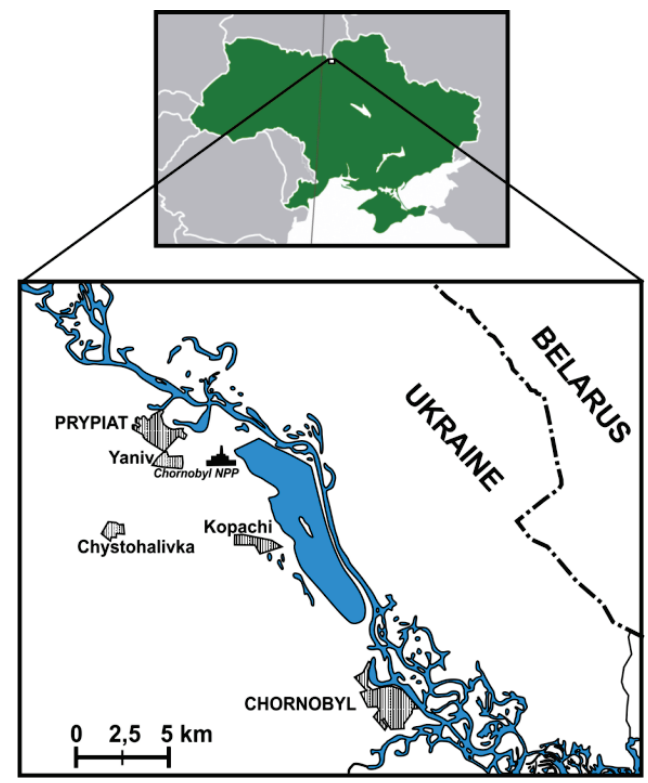

Fig. 1. Locations of cultivation of winter wheat $\left(\mathrm{M}_{1}\right)$ within the Chornobyl Plant Alienation Zone

The record of frequency and the range of mutant forms were performed only in generation $\mathrm{M}_{3}$ after checking the inherited altered traits according to the ratio of the number of families with mutant plants to the examined $\mathrm{M}_{2}$ families. Mutations valuable for selective breeding were considered to be inherited changes that contribute to yield, increase in grain quality and resistance of the plants to deleterious abiotic and biotic environmental factors. The level of induction of beneficial mutations was determined according to the ratio of the number of detected beneficial mutations to the overall number of examined families in $\mathrm{M}_{2}$ and according to their share of the total amount of detected mutant changes.

Table 1

Density of soil pollution with radionuclides (according to the State Specialized Enterprise Chornobylsky Spetskombinat)

\begin{tabular}{lcccccc}
\hline \multirow{2}{*}{$\begin{array}{c}\text { Radio- } \\
\text { nuclides }\end{array}$} & \multicolumn{6}{c}{ Sampling location } \\
\cline { 2 - 7 } & \multicolumn{1}{c}{ Chystohalivka village } & \multicolumn{2}{c}{ Kopachi village } & \multicolumn{2}{c}{ Yaniv village } \\
\cline { 2 - 7 } & $\mathrm{Bq} / \mathrm{kg}$ & $\mathrm{kBq} / \mathrm{m}^{2}$ & $\mathrm{~Bq} / \mathrm{kg}$ & $\mathrm{kBq} / \mathrm{m}^{2}$ & $\mathrm{~Bq} / \mathrm{kg}$ & $\mathrm{kBq} / \mathrm{m}^{2}$ \\
${ }^{137} \mathrm{Cs}$ & 7013 & 526 & 3557 & 267 & 28000 & 2100 \\
${ }^{9} \mathrm{Sr}$ & 789 & 59.20 & 1275 & 95.60 & 1067 & 80.0 \\
${ }^{241} \mathrm{Am}$ & 129 & 9.64 & 46 & 3.44 & 147 & 11.0 \\
${ }^{239,240} \mathrm{Pu}$ & 108 & 8.10 & 53 & 3.99 & 88 & 6.6 \\
${ }^{238} \mathrm{Pu}$ & 45 & 3.38 & 23 & 1.78 & 36 & 2.7 \\
\hline
\end{tabular}

Note: overall specific radioactivity of soil in Hlevaha urban-type settlement in Kyiv Oblast is $290 \mathrm{~Bq} / \mathrm{kg}\left(21.8 \mathrm{kBq} / \mathrm{m}^{2}\right)$. 
Statistical analysis of the experimental data was made using the generally accepted methods, the significance of the differences was assessed using ANOVA. The tables present percentages of mutations and mean errors of samples' mean arithmetic values.

\section{Results}

Ionizing radiation throughout the vegetative period of the winter wheat plant within $10 \mathrm{~km}$ of the Chornobyl Alienation Zone (Chystohalivka, Kopachi, Yaniv villages) 30 years after the accident caused increase in the level of noticeable mutations, frequency of which exceeded the control values $(0.81 \%$ for Albatros Odesky and $0.58 \%$ for Zymoiarka variety) by $8.0-14.9$ times (Table 2 ). In the territories with highest radionuclide pollution - Chystohalivka village (exposure dose was $28.7 \cdot 10^{-12}$ $\mathrm{A} / \mathrm{kg}$ ) and Yaniv village (exposure dose was $50.0 \cdot 10^{-12} \mathrm{~A} / \mathrm{kg}$ ), we observed maximum frequency of mutations, which accounted for $12.0 \%$ among Albatros Odesky variety and $6.9 \%$ and $7.0 \%$ respectively for Zymoiarka variety.

\section{Table 2}

Frequency of noticeable mutations in winter wheat in $\mathrm{M}_{2}-\mathrm{M}_{3}$ generations, induced by radionuclide contamination in the Chornobyl Plant Alientation Zone $(\mathrm{x} \pm \mathrm{SD})$

\begin{tabular}{|c|c|c|c|c|}
\hline Variety & $\begin{array}{l}\text { Cultivation } \\
\text { location }\end{array}$ & $\begin{array}{c}\text { Number of } \\
\text { examined } \\
\text { families }\end{array}$ & $\begin{array}{l}\text { Number } \\
\text { of mutant } \\
\text { families }\end{array}$ & $\begin{array}{l}\text { Frequency } \\
\text { of mutant } \\
\text { families, } \%\end{array}$ \\
\hline \multirow{3}{*}{$\begin{array}{l}\text { Albatros } \\
\text { Odesky }\end{array}$} & $\begin{array}{l}\text { Hlevaha urban-type } \\
\text { settlement (control) }\end{array}$ & 494 & 4 & $0.81 \pm 0.40$ \\
\hline & Chystohalivka village & 241 & 29 & $12.03 \pm 2.10 * * *$ \\
\hline & Kopachi village & 497 & 37 & $7.44 \pm 1.18^{* * *}$ \\
\hline \multirow{4}{*}{ Zymoiarka } & $\begin{array}{l}\text { Hlevaha urban-type } \\
\text { settlement (control) }\end{array}$ & 522 & 3 & $0.58 \pm 0.33$ \\
\hline & Chystohalivka village & 413 & 29 & $7.02 \pm 1.26^{* * *}$ \\
\hline & Kopachi village & 345 & 16 & $4.64 \pm 1.13^{* * *}$ \\
\hline & Yaniv village & 480 & 33 & $6.88 \pm 1.16^{* * *}$ \\
\hline
\end{tabular}

Note: ***-difference is statistically significant compared with the control at $\mathrm{P}<0.001$.

Exposure dose at the examined plot located in Kopachi village $\left(7.2 \cdot 10^{-12} \mathrm{~A} / \mathrm{kg}\right.$ ) was the lowest, 4.0-6.9 times lower than the exposure doses within Chystohalivka and Yaniv villages. However, even in the conditions of cultivation of winter wheat in the territory of Kopachi, we determined a high level of mutation variability (7.4\% for plants of Albatros Odesky variety and $4.6 \%$ for Zymoiarka variety) that exceeded the control values by 9.2 and 8.0 times and was not significantly different from the frequency of mutations induced by radionuclide contamination in the territories of Chystohalivka and Yaniv villages.

The range of mutations was determined according to the number of types of inherited changes that were found in induced mutants. The range of mutations in $\mathrm{M}_{2}-\mathrm{M}_{3}$ generations of winter wheat plants, which were caused by prolonged action of the emission of radionuclide pollutions of the neighboring Chornobyl Power Plant Zone 30 years after the accident, included 12-20 types and depended on density of soil contamination and exposure dose, as well as genotype of winter wheat plants. Among them, the mutations expressed in duration of vegetative period, length of the stem, morphology of the ear, presence or absence of awns (Fig. 2-4).

In all the studied territories under the increased radiation fund, the mutant plants observed in high frequency were late maturing (0.60-2.92\%), low $(2.03-2.49 \%)$ forms, mutants with dense (0.81-2.32\%), squarehead $(0.20-0.87 \%)$ ear. Tall mutants and mutants with intense growth rates, despite being exclusively typical consequences of chronic radiation within the Alienation Zone of Chornobyl, were seen with the frequency exceeding the control parameters significantly (Table 3). Such mutations as short, non-dense, semi-sterile ear occurred in winter wheat plants growing in the conditions of chronic radiation in the territories with the highest density of soil contamination with radionuclides - villages Chystohalivka and Yanic, and a statistically significant increase in frequency of long ear mutation ( $0.81 \%$ in Albatros Odesky variety) was observed in the conditions of the lowest density of radionuclide contamination in Kopachi village. Some types of mutations had a variety-specific pattern of manifestation, and the frequency with which they occurred did not depend on density of radionuclide contamination. Therefore, mutations such as glaucous ear, anthocyanin leaves and awns, were found only among plants of Albatros Odesky variety, with frequency equaling respectively $1.01-1.25 \%, 0.20-0.83 \%$ and $0.40-1.66 \%$. Mutation of early maturation, characteristic for Zymoiarka variety, was seen with $0.19-0.63 \%$ frequency. Among the types of mutations in Albatros Odesky plants induced by radionuclide contamination in the territories of Chystohalivka village, we distinguished a number of original noticeable inherited changes, including speltoid ear $(0.42 \%)$, red anthers $(0.42 \%)$, wide $(0.83 \%)$, narrow $(0.42 \%)$ and light green $(0.83 \%)$ leaves. Erectoid ear mutation $(0.20 \%)$ was also found in plants of this species, but in the conditions of influence of radionuclide contamination in Kolpachi village. In winter wheat plants of Zymoiarka variety, the heightened radioactive background of radionuclide-contaminated territories induced a significantly narrower range of mutant types, including such an untypical mutation as absence of waxy layer $(0.20 \%)$, caused by radiation impact developed in the territory of Kopachi village.

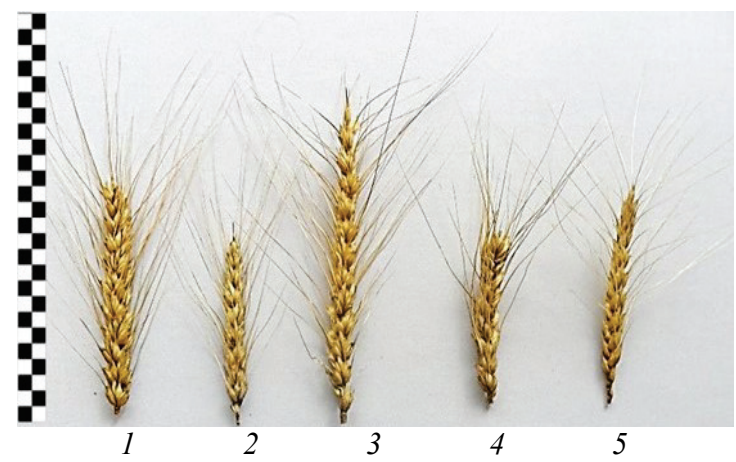

Fig. 2. Mutations according to the morphology of the ear in winter wheat of Albatros Odesky variety, induced in the Chornobyl Alientation Zone: 1 - initial form of the ear, 2 - short ear, 3 -long ear, 4-squarehead ear, 5-speltoid ear

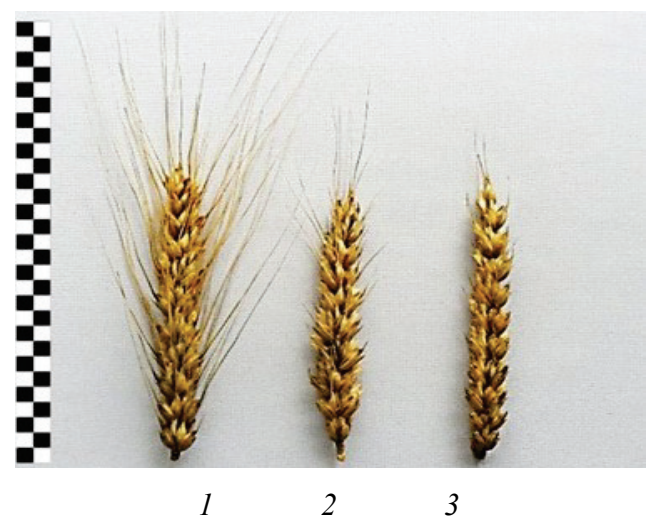

Fig. 3. Mutations of awns of the ear of winter wheat of Albatros Odesky variety, induced in the Chornobyl Alienation Zone: 1 -awned ear of the initial form, 2 - semi-awned ear, 3-awnless ear

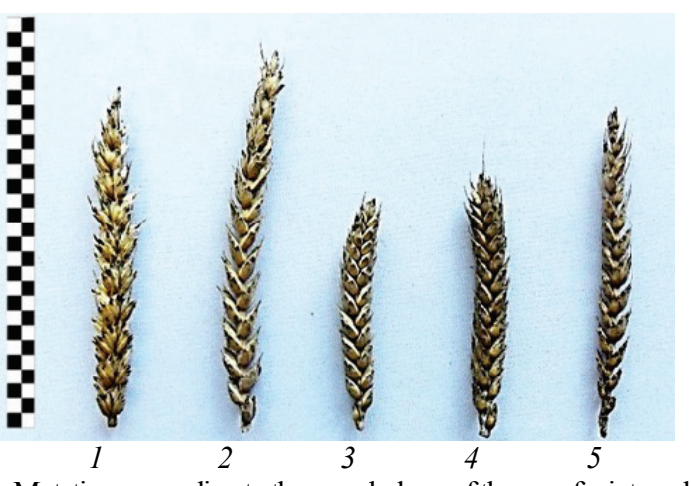

Fig. 4. Mutations according to the morphology of the ear of winter wheat of Zymoiarka variety, induced in the Chornobyl Alienation Zone: 1 - initial form of the ear, 2 - long ear, 3 - short dense ear, 4 -squarehead ear, 5-speltoid ear 


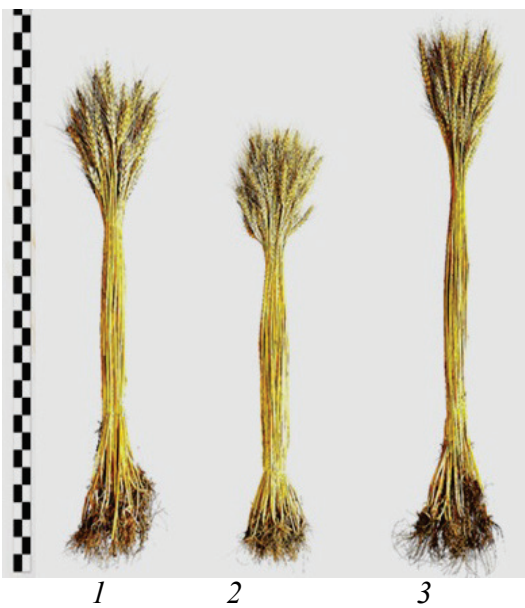

Fig. 5. Mutations in stem length among plants of Albatros Odesky winter wheat, induced in the Chornobyl Alienation Zone: 1 -initial length of the stem, 2 - low height, 3 - tall height

As a result of the analysis of the spectrum of noticeable mutations in $\mathrm{M}_{2}-\mathrm{M}_{3}$ generations of the plants, we found plants and some samples with multiple combinations of discovered traits. Among them, we distingui shed tall forms with intense growth and broad leaves; tall, late maturing, with intense growth, light green colour and non-dense ear; tall, late maturing, with light green narrow leaves and red anthers; low, awnless, with short dense ear in plants of Albatros Odesky variety and tall, early maturing, with intense growth; late matured, with dense cylindrical or short ear and absence of waxy layer; with semi-awned non-dense ear; low, with squarehead ear in plants of Zymoiarka variety.

In the conditions of chronic impact of ionizing radiation in the Chornobyl Alienation Zone, the frequency of useful selection mutations exceeded the control level by 35.3-35.4 times for Albatros Odesky variety and 20.9-26.8 times for Zymoiarka variety, equaling respectively 7.05$7.07 \%$ and $3.97-5.09 \%$ (Table 4).

Their range included forms with long, large, cylindrical ear, shortened stem, intense growth, early maturation. Their share in the overall amount of mutations in Albatros Odesky plants grown in Chystohalivka village was at the level of the control $(24.7 \%)$, whereas the percentage of useful selection mutations in the conditions of radionuclide contamination in Kopachi territory accounted for $49.3 \%$, which statistically significantly exceeded the control parameters. The dominating forms among them were low, with intense growth and long ear. In plants grown in Kopachi, highly frequent mutation was also early maturation. Under the conditions of radionuclide contamination, we observed mutations such as large and cylindrical ears with lower frequency.

Table 3

Spectrum of noticeable mutations (\%) in winter wheat of $\mathrm{M}_{2}-\mathrm{M}_{3}$ generations, cultivated in the Chornobyl Plant Alienation Zone

\begin{tabular}{|c|c|c|c|c|c|c|c|}
\hline \multirow[b]{2}{*}{ Types of mutations } & \multicolumn{4}{|c|}{ Albatros Odesky } & \multicolumn{3}{|c|}{ Zymoiarka } \\
\hline & $\begin{array}{l}\text { Hlevaha urban-type } \\
\text { settlement (control) }\end{array}$ & $\begin{array}{l}\text { Chystohalivka } \\
\text { village }\end{array}$ & Kopachi village & $\begin{array}{l}\text { Hlevaha urban-type } \\
\text { settlement (control) }\end{array}$ & $\begin{array}{l}\text { Chystohalivka } \\
\text { village }\end{array}$ & Kopachi village & Yaniv village \\
\hline 1 & $0.20 \pm 0,20$ & 0 & $1.01 \pm 0.45^{\#}$ & 0 & $0.73 \pm 0.42$ & $1.45 \pm 0.64^{* \wedge}$ & 0 \\
\hline 2 & 0 & 0 & 0 & $0.19 \pm 0.19$ & $0.48 \pm 0.34$ & 0 & $0.63 \pm 0.36$ \\
\hline 3 & 0 & $2.91 \pm 1.01^{* *}$ & $0.60 \pm 0.34^{\#}$ & 0 & $1.21 \pm 0.53^{*}$ & $1.45 \pm 0.64 *$ & $2.92 \pm 0.76^{* * *}$ \\
\hline 4 & 0 & $2.91 \pm 1.01 * *$ & $1.81 \pm 0.60^{* *}$ & $0.19 \pm 0.19$ & $1.70 \pm 0.63^{*}$ & $0.29 \pm 0.28^{\#}$ & $0.63 \pm 0.36$ \\
\hline 5 & $0.61 \pm 0.35$ & $5.81 \pm 1.51 * * *$ & $3.22 \pm 0.79 * *$ & $0.19 \pm 0.19$ & $1.94 \pm 0.68^{*}$ & $0.29 \pm 0.28^{\#}$ & $1.04 \pm 0.46$ \\
\hline 6 & 0 & $2.49 \pm 1.00 *$ & $2.42 \pm 0.59 * * *$ & 0 & $2.18 \pm 0.72 * *$ & $2.03 \pm 0.76^{* *}$ & $2.29 \pm 0.68^{* * *}$ \\
\hline 7 & 0 & $1.25 \pm 0.71$ & $0.81 \pm 0.40^{*}$ & 0 & 0 & $0.29 \pm 0.28$ & $0.42 \pm 0.29$ \\
\hline 8 & 0 & $1.25 \pm 0.71$ & $0.20 \pm 0.20$ & 0 & 0 & $0.87 \pm 0.50$ & $0.83 \pm 0.41 *$ \\
\hline 9 & 0 & $0.42 \pm 0.41$ & $0.60 \pm 0.34$ & 0 & $0.24 \pm 0.24$ & 0 & 0 \\
\hline 10 & 0 & $1.66 \pm 0.82 *$ & $0.81 \pm 0.40 *$ & 0 & $0.97 \pm 0.48^{*}$ & $2.32 \pm 0.81^{* *}$ & $0.83 \pm 0.41 *$ \\
\hline 11 & 0 & $2.08 \pm 0.92^{*}$ & 0 & 0 & $0.24 \pm 0.24$ & $0.29 \pm 0.28$ & $0.21 \pm 0.20$ \\
\hline 12 & 0 & 0 & $0.40 \pm 0.28$ & 0 & $0.24 \pm 0.24$ & $0.58 \pm 0.41$ & $0.63 \pm 0.37$ \\
\hline 13 & 0 & $0.83 \pm 0.58$ & $0.20 \pm 0.20$ & 0 & 0 & $0.87 \pm 0.50$ & $0.42 \pm 0.29$ \\
\hline 14 & 0 & $0.42 \pm 0.41$ & 0 & 0 & 0 & 0 & 0 \\
\hline 15 & 0 & 0 & $0.20 \pm 0.20$ & 0 & 0 & 0 & 0 \\
\hline 16 & 0 & $0.42 \pm 0.41$ & 0 & 0 & $0.24 \pm 0.24$ & 0 & 0 \\
\hline 17 & 0 & $0.42 \pm 0.41$ & $0.20 \pm 0.20$ & 0 & 0 & 0 & 0 \\
\hline 18 & 0 & 0 & $0.20 \pm 0.20$ & 0 & $0.24 \pm 0.24$ & $0.58 \pm 0.41$ & $0.42 \pm 0.29$ \\
\hline 19 & 0 & 0 & 0 & 0 & 0 & 0 & $0.21 \pm 0.20$ \\
\hline 20 & 0 & $1.25 \pm 0.71$ & $1.01 \pm 0.45^{*}$ & 0 & 0 & 0 & 0 \\
\hline 21 & 0 & $1.66 \pm 0.82^{*}$ & $0.40 \pm 0.28$ & 0 & 0 & 0 & 0 \\
\hline 22 & 0 & $0.42 \pm 0.41$ & 0 & 0 & 0 & 0 & 0 \\
\hline 23 & 0 & $0.83 \pm 0.58$ & 0 & 0 & 0 & 0 & 0 \\
\hline 24 & 0 & $0.42 \pm 0.41$ & 0 & 0 & 0 & 0 & 0 \\
\hline 25 & 0 & $0.83 \pm 0.58$ & $0.20 \pm 0.20$ & 0 & 0 & 0 & 0 \\
\hline 26 & 0 & $0.83 \pm 0.58$ & 0 & 0 & 0 & 0 & 0 \\
\hline 27 & 0 & 0 & 0 & 0 & 0 & $0.58 \pm 0.41$ & 0 \\
\hline Number of mutant types & 2 & 20 & 17 & 3 & 12 & 13 & 13 \\
\hline
\end{tabular}

Note: types of mutations: 1 - early maturation, 2 -average-early maturation, 3 - late maturation, 4 -intense growth, 5 -tallness, 5 - low height, 7 -long ear, 8 - short ear, 10 dense ear, 11 - non-dense ear, 12 - cylindrical ear, 13 - squarehead ear, 14 - speltoid ear, 15 - erectoid ear, 16 - semi-sterile ear, 17 -awnless ear, 18 - semi-awned ear, 19 awned ear, 20 - glaucous ear, 21 - anthocyanin awns, 22 - red anthers, 23 - broad leaf, 24 - narrow leaf, 25 - anthocyanin leaves, 26 - light green leaves, 27 absence of waxy layer, *-difference was considered statistically significant compared to the control at $\mathrm{P}<0.05 ; * *$-difference is considered statistically significant compared to the control at $\mathrm{P}<$ 0.01 ; *** - difference is considered statistically significant compared to the control at $\mathrm{P}<0.001$; \#-difference compared to the variant in Chystohalivka village is statistically significant at $\mathrm{P}<0.05 ; \wedge$ - difference compared to the variant in Yaniv village is statistically significant at $\mathrm{P}<0.05$.

Table 4

Frequency of useful selection mutations (\%) in winter wheat in $\mathrm{M}_{2}-\mathrm{M}_{3}$ generations, induced in the Chornobyl Alienation Zone $(\mathrm{n}=400, \mathrm{x} \pm \mathrm{SD})$

\begin{tabular}{|c|c|c|c|c|}
\hline \multirow[b]{2}{*}{ Sampling locations } & \multicolumn{2}{|c|}{ Albatros Odesky } & \multicolumn{2}{|r|}{ Zymoiarka } \\
\hline & $\begin{array}{c}\text { Frequency } \\
\text { of beneficial mutations }\end{array}$ & $\begin{array}{l}\text { Share of beneficial mutations in the } \\
\text { overall amount of detected mutations }\end{array}$ & $\begin{array}{c}\text { Share } \\
\text { of beneficial mutations }\end{array}$ & $\begin{array}{l}\text { Share of beneficial mutations in the } \\
\text { overall amount of detected mutations }\end{array}$ \\
\hline Hlevaha urban-type settlement (control) & $0.20 \pm 0.08$ & $24.69 \pm 1.94$ & $0.19 \pm 0.06$ & $33.33 \pm 2.06$ \\
\hline Chystohalivka village & $7.07 \pm 1.65^{* * *}$ & $24.29 \pm 2.76$ & $5.09 \pm 1.08^{* * *}$ & $48.90 \pm 2.46^{*}$ \\
\hline Kopachi village & $7.05 \pm 1.15^{* * *}$ & $49.34 \pm 2.24 * *$ & $4.64 \pm 1.13^{* * *}$ & $39.02 \pm 2.63$ \\
\hline Yaniv village & - & - & $3.97 \pm 0.89 * * *$ & $34.58 \pm 2.17$ \\
\hline
\end{tabular}

Note: *-difference compared to the control is statistically significant at $\mathrm{P}<0.05 ; * *$ - difference compared to the control is statistically significant at $\mathrm{P}<0.01 \cdot * * *$ - difference compared to the control is statistically significant at $\mathrm{P}<0.001$. 
The peculiarity of the genotype reaction of Zymoirka plants to radionuclide contamination in the territory of Chystohalivka village was significant increase in the percentage of beneficial agronomic mutations, which accounted for $48.9 \%$. Excess over the control values according to the share of beneficial mutations was also observed in the conditions of radioactive contamination in the territories of Kopachi and Yanivvillages, though their percentage was significantly inferior to such observed in the conditions of Chystohalivka village. In most cases, they contained forms that matured early, low, with intense growth and cylindrical ear.

Important selection mutations were often accompanied by morphologically inherited changes, which may have been factors of significant reduction of plants' productivity. Therefore, the long ear mutation was found in a complex with long stem trait; mutation of low height was seen accompanied by short or squarehead ears; plants with intense growth were characterized by tall height at the same time and non-dense ear; the valuable selection breeding trait of early maturation was found together with tall height and non-dense ear; plants with large ear were characterized by late maturation, while the cylindrical ear mostly was also small sized.

\section{Discussion}

Among the agricultural crops that grew in pre-disaster period in the territory of Chornobyl Alienation Zone and were sown over a large area of land, there were the following cereal crops: winter bread wheat (Triticum aestivum L.) and rye (Secale cereale L.) (Morgun \& Yakymchuk, 2021). Since the first months following the accident, they have become some of the commonest plants studied concerning the genetic effects of the Chornobyl disaster and have lost no relevance to this day. Winter bread wheat has a complex genetic nature because of hexaploidity and therefore a great reserve of variance (Krotova \& Beletskaya, 2015). Selection of original mutations and re-combinations, combination of mutation and combinatory variabilities are the main methods of gene fund enrichment (Makeen \& Babu, 2010). Creation of new and improvement of existing genetic sources of grasses through mutations allow improvement of the frequency of crossing over, shifting trait dominations, altering effects of gene interaction, which ultimately leads to more complete implementation of inherited variability (Makeen \& Babu, 2010). In the conditions of induced mutagenesis, from one genotype, one may derive quite a broad variety of forms, particularly those with different beneficial traits. Use of mutagens that have emerged in already existing varieties allows one to operate highly beneficial proportions of positive traits (compared to negative) against the homogenous general background of genome of cultivated variety. Furthermore, as the material for cross breeding, there may be used mutants with induced positive traits that do not occur in existing varieties. Mutagenic factors with low frequency led to emergence of mutants that are not of great interest individually, though they have heightened parameters of the complex of quantitative useful selective breeding traits that would be expedient to transfer to other mutants or varieties. Creating new varieties with high and stable yield against the background of varying ecological conditions is based on morphologically variable parent material and integrated study of it.

The mutagens that have been used most commonly in the practice of experimental mutagenesis include ionizing radiation and chemical supermutagens. Study of the peculiarities of molecular mechanisms of their action allowed a development of methods of their most efficient application to improve the frequency and broaden the range of mutations, particularly the ones useful for selective breeding. Taking into account positive results of using combined action of mutagenic factors of different nature in high and low doses, the next question is the potential of using territories that have been anthropogenically contaminated by mutagenic factors as polygons with unique conditions of influence of complex of natural and technogenic genotoxic factors that may cause unpredictable genetic consequences. In Ukraine, such a polygon has for 35 years been the Chornobyl Alienation Zone.

Chronic radiation influencing the winter wheat in the Alienation Zone in remote period since the Power Plant disaster led to mutations in plants, the frequency of which has not been accompanied by direct dependence on the density of radionuclide contamination. In particular, in the conditions of difference between the exposure doses $\left(21.3 \cdot 10^{-12} \mathrm{~A} / \mathrm{kg}\right)$, found in the territories of Chystohalivka and Yaniv villages, no significant difference in frequencies of the observable mutations were determined. The frequency of mutations was also not significantly different in the conditions of chronic exposure of plants to the radiation in the territory of Kopachi village, where the exposure dose was the lowest, 4.0-6.9 times lower than those within Chystohalivka and Yaniv villages. Long-lasting action of high doses of radiation is believed to induce a number of nonvital mutants that were not taken into account in the overall frequency of mutations (Mousseau \& Møller, 2020). Non-linear pattern of induction of mutations in the organisms that are subject to chronic exposure in the territories with different levels of specific activity of radionuclides was found in many tested plants: narrowleaf hawksbeard Crepis tectorum, Scots pine Pinus sylvestris, pea Pisum sativum, winter rye, winter wheat, barley (Zaichkina et al., 2004; Geras'kin et al., 2008; Boratyński et al., 2016; Olsen \& Dineva, 2017; Morgun et al., 2019; Hase et al., 2020; Shuryak \& Brenner, 2021).

Some studies clearly revealed that the frequency of mutations per unit of absorbed dose against the background of lowest levels of contamination $\left(5-10 \mathrm{Ci} / \mathrm{km}^{2}\right)$ was 16-fold higher than in the conditions of high doses (400-500 Ci/ $\left.\mathrm{km}^{2}\right)$ (Sidorov, 1994). Over the period from germinations to microspore genesis and gametogenesis, the barley plants of waxyline grown in two experimental plots in Chornobyl and within Yanic village had been exposed to radiation doses of $0.05,2.56$ and $21.12 \mathrm{cGy}$. Mutation frequency in calculation per unit of the dose was higher than such in the least contaminated plots (Boubriak et al., 2016). The authors indicate that in the conditions of gamma radiation field, the frequency of waxyreversions was increasing linearly, while in the conditions of the Chornobyl Zone - exponentially. Decrease in mutagenic effects during high levels of radionuclide contamination was also observed in wild-growing populations of Arabidopsis (Geras'kin et al., 2008), which is attributed to decrease in efficiency of DNA reparation. Inhibition of the system of DNA recovery is associated with SOS-reparation, which ultimately leads to relative decrease in mutagenesis at high levels of radionuclide contamination. Non-linear dependence of the effect on the radiation dose is indicated by the results of the studies conducted on winter wheat (Morgun \& Yakymchuk, 2010; Yakymchuk, 2019). Therefore, as the level of radionuclide contamination in territory of the Alienation Zone gradually decreases, we should expect that high mutagenic effect of the radiation shall remain.

Acute radiation that is often used in laboratory conditions to induce the mutations usually take impact in a short period of time during exposure to high doses. Chronic exposure to radiation, observed in radionuclide-contaminated territories of the Chornobyl Alienation Zone, is continuous and often affects a significant part of life of an organism. Usually, chronic radiation is active during separate life stages and in quite low doses, causing no heavy radioactive impacts. The difference between genetic consequences of acute and chronic emissions in the Chornobyl Alienation Zone may be explained by the fact that the plants are subject to various types of both external and internal radiations, the concentration of radionuclides in the growth zones, their synergy with chemical toxicants that may influence the level of genetic impact. Also, the chronic effect of ionizing radiation related to the Power Plant disaster is believed to occur through components that are still unknown (Boubriak et al., 2016; Sanzharova \& Fesenko, 2018). During the ontogenesis, there were recorded several obstacles for organisms damaged by $\gamma$-radiation to continue to exist (Pozolotina, 2003): 1) beginning of functioning of the meristematic tissues, 2) gametogenesis, which coincides with blossom phase, 3) embryo development stage. All the existing barriers guarantee no complete disappearance of changes caused by $\gamma$-radiation in the subsequent generations, but undergoing them is a necessary condition for preservation and transfer of complete genetic information to offspring.

Thirty years after the accident, chronic exposure to radionuclide contamination in the Alienation Zone induced quite a broad spectrum of noticeable mutations in winter wheat, ranging 12-20 types. Most of them were mutation changes related to height of the plants, structure of the ear, presence or absence of awns, duration of the vegetative period. The spectrum of mutations was characteristic of relatively frequent emergence of mutations related to the dwarfism (dwarf and low forms), which occurs quite rarely in the conditions of spontaneous variability and is of low fre- 
quency during experimental mutagenesis. Considering that similar forms were found among the material collected during the year of the Chornobyl disaster in most affected Oblasts of Ukraine (Morgun \& Yakymchuk, 2021), occurrence of height-related mutations among plants is obviously a distinctive consequence of the radiation in the contaminated territories. The mutations included red awns of the ear, red anthers, anthocyanincoloured leaves. Detection of anthocyanin colour on various organs of the plants in the process of ontogenesis is a reaction of plants to unfavourable abiotic and biotic environmental factors, which may correlate with the level of radionuclide contamination and degree of adaptation to ionizing radiation (Guscha et al., 2002; Shoeva et al., 2017; Shoeva \& Khlestkina, 2018). The red colour of organs of plants is controlled by a number of genes: $R_{c}$ - determines the colour of coleoptile, $R_{a}-$ colour of the leaf base and the "ears" of the leaf axil, $\mathrm{P}_{\mathrm{an}}-$ anthers in blossom phase, $\mathrm{P}_{\mathrm{c}}-$ colour of the stem in the early period of ripening of seeds, $R_{g}$ and $R$ - colours of ear scales and grains (Hlestkina, 2012; Jiang et al., 2018; Jia et al., 2020; Abrouk et al., 2021). Emergence of distinct mutants with squareheaded, speltoid and erectoid ears is related to deletion, deletion-duplication, translocation, microabberations in the fifth chromosome of A genome, which contains locus Q (Konopatskaia et al., 2016; Simonov et al., 2017). Its deletion is likely to determine speltoid features. Squareheaded plants may have been conditioned by duplications, translocations, microabberations related to increase in dose of $\mathrm{Q}$ locus, and also trisomy of $5 \mathrm{~A}$ chromosome. Erectoid types occur as a result of monosomy, but the missing chromosome has not yet been identified.

The degree of genotoxicity of mutagenic factor is not only the frequency level of mutations, but also their simultaneous complex presence in one cell or entire organism. Induction of multiple mutations can be used to overcome some undesirable relationships between the traits and combine such features in one mutant, which are hard to compose (Abdelaleema \& Al-Azab, 2021). Radiation towards hybrid populations of winter wheat plants was also confirmed to increase successful selection of recombinants with more favourable combinations of useful traits than in case with regular hybrid populations (Beyaz \& Yildiz, 2017).

In the studies of frequencies and the spectrum of mutations induced by various mutagenic factors, it is important to determine the share of beneficial agronomic ones. Such features may include resistance to unfavourable environmental conditions, diseases and pests, increased yield, high quality of grain and bread, heightened amount of protein and essential aminoacids, high adaptive properties, etc (Morgun \& Yakymchuk, 2010; Mir et al., 2020). One of the problems of chronic action of radiation is that its biological consequences are impossible to predict, as well as to determine direct dependence of initial beneficial agronomic mutations on the overall level of mutations. The results of our studies may also be an example when two varieties of one crop were observed to have different frequencies of useful selective breeding mutations after exposure to the same doses. Therefore, Albatros Odesky variety had increase in the share of beneficial selective breeding mutations in the conditions of exposure to radionuclide contamination of soil in the territory of Kopachi village, where specific radioactivity was the lowest. Frequency of useful selection mutations induced by radionuclide soil pollution within Chystohalivka and Yaniv villages were at the same level and significantly exceeded the control. Zymoiarka variety had the highest share of important selection mutations in the conditions of chronic radiation influencing plants in Chystohalivka village, and was no different from the parameters of the control in the conditions of cultivating winter wheat under the influence of highest and lowest specific radiations in soil in Yaniv and Kopachi villages.

\section{Conclusions}

Despite significant improvement in the radiological situation in the Chornobyl Alienation Zone, the level of mutation variability in winter wheat is high even 30 years following the accident, exceeding the control by 8.0-14.9 times. In places with most intense radionuclide contamination (Chystohalivka and Yaniv villages), we found the highest frequency of mutations $-12.0 \%$ for Albatros Odesky variety and $6.9 \%$ and $7.0 \%$ for Zymoiarka variety. Mutation variability of winter wheat also remained at a high level in the area where the exposure dose decreased 6.9-fold (territory of Kopachi village), exceeding the control parameters respectively by
9.2 and 8.0 times, and was not different from the frequency of mutations induced by radionuclide contamination in Chystohalivka and Yaniv villages. Therefore, as the level of radionuclide contamination in the Chornobyl Alienation Zone gradually decreases, one may further expect maintenance of high mutagenic effect of the radiation. The spectrum of mutations which have been caused by long-term impact of radionuclide contamination in the area next to the Alienation Zone comprised 12-20 types, depending on density of soil contamination with radionuclides and magnitude of radiation dose, as well as genotype of plants. Among the determined mutations, $24.3-49.3 \%$ accounted for important agronomic mutations, the dominating being low height, intense growth and long cylindrical ear. The high likelihood of inheriting beneficial agronomic traits in complex with mutations that reduce productivity of winter wheat limits the efficiency of direct selection of beneficial selective breeding mutant forms. Enlargement of genetic diversity of initial material for selective breeding on account of mutagenesis induced by radionuclide contamination creates perspectives for its use in cross-breeding with the purpose of implementation of selective breeding genetic programs aimed at improving wheat varieties.

\section{References}

Abdelaleema, M. A., \& Al-Azab, K. F. (2021). Evaluation of flour protein for different bread wheat genotypes. Brazilian Journal of Biology, 81(3), 719-727.

Abrouk, M., Athiyannan, N., Müller, T., Pailles, Y., Stritt, C., Roulin, A. C., Chu, C., Liu, S., Morita, T., Handa, H., Poland, J., Keller, B., \& Krattinger, S. G. (2021). Population genomics and haplotype analysis in spelt and bread wheat identifies a gene regulating glume color. Communications Biology, 4, 1-11.

Akleev, A. V. (2009). Reaktsii tkaney na hronicheskoe vozdeystvie ioniziruyuschego izlucheniya [Tissue reactions to chronic exposure to ionizing radiation]. Radiation Biology, Radioecology, 49(1), 5-20 (in Rassian).

Anders, S., Cowling, W., Pareek, A., Gupta, K. J., Singla-Pareek, S. L., \& Foyer, C. H. (2021). Gaining acceptance of novel plant breeding technologies. Trends in Plant Science, 26(6), 575-587.

Beljaev, V. I., Vol'nov, V. V., Sokolova, L. V., Kuznecov, V. N., \& Matsyura, A. V. (2017). Effect of sowing techniques on the agroecological parameters of cereal crops. Ukrainian Journal of Ecology, 7(2), 130-136.

Beyaz, B. R., \& Yildiz, M. (2017). The use of gamma irradiation in plant mutation breeding. IntechOpen, London.

Bezpal'ko, V. V., Stankevych, S. V., Zhukova, L. V., Zabrodina, I. V., Turenko, V.P., Horyainova, V. V., Poedinceva, A. A., Batova, O. M., Zayarna, O. Y., Bondarenko, S. V., Dolya, M. M., Mamchur, R. M., Drozd, P. Y., Sakhnenko, V. V., \& Matsyura, A. V. (2020). Pre-sowing seed treatment in winter wheat and spring barley cultivation. Ukrainian Journal of Ecology, 10(6), 255-268.

Bhutta, S. K., Bhutta, K. N., Aslam, M. N., Nasir, I. R., \& Ali, M. A. (2019). Evaluation of growth and yield attributes of some wheat varieties under local conditions of Southern Punjab, Pakistan. Journal of Plant Breeding and Genetics, 7(1), 19-25.

Boratyński, Z., Arias, J. M., Garcia, C., Mappes, T., Mousseau, T. A., Møller, A. P., Pajares, A. J. M., Piwczyński, M., \& Tukalenko, E. (2016). Ionizing radiation from Chernobyl affects development of wild carrot plants. Scientific Reports, 6 , 39282.

Boubriak, I., Akimkina, T., Polischuk, V., Dmitriev, A., McCready, S., \& Grodzinsky, D. (2016). Long term effects of Chernobyl contamination on DNA repair function and plant resistance to different biotic and abiotic stress factors. $\mathrm{Cy}$ tology and Genetics, 50(6), 381-399.

Burdeniuk-Tarasevych, L. A., Lozinskyi, M. V., \& Dubova, O. A. (2015). Osoblyvosti formuvannia dovzhyny stebla u selektsiinykh nomeriv pshenytsi ozymoji zalezhno vid yikh henotypiv ta umov vyroshchuvannia [The peculiarities of the formation of the stem in the selection numbers of winter wheat are depend on the genotype and conditions of growing]. Agrobiology, 1, 11-15 (in Ukrainian).

Eyges, N. S. (2013). Istoricheskaya rol Iosifa Abramovicha Rapoporta v genetike. Prodolzhenie issledovaniy s ispolzovaniem metoda himicheskogo mutageneza [The historical role of Joseph Abramovich Rapoport in genetics. Continued research using the method of chemical mutagenesis]. Vavilov Journal of Genetics and Breeding, 17(1), 162-172 (in Russian).

Geras'kin, S. A., Fesenko, S. V., \& Alexakhin, R. M. (2008). Effects of non-human species irradiation after the Chernobyl NPP accident. Environment International, 34(6), 880-897.

Godwin, I. D., Rutkoski, J., Varshney, R. K., \& Hickey, L. T. (2019). Technological perspectives for plant breeding. Theoretical and Applied Genetics, 132, 555-557.

Gubatov, T., \& Delibaltova, V. (2020). Evaluation of wheat varieties by the stability of grain yield in multienvironmental trails. Bulgarian Journal of Agricultural Science, 26(2), 384-394. 
Guscha, N. I., Perkovskaya, G. Y., Dmitriev, A. P., \& Grodzinskiy, D. M. (2002). Vliyanie hronicheskogo oblucheniya na adaptivnyiy potentsial rasteniy [Influence of chronic irradiation on the adaptive potential of plants]. Radiation Biology, Radioecology, 42(2), 155-158 (in Rassian).

Hase, Y., Satoh, K., Seito, H., \& Oono, Y. (2020). Genetic consequences of acute/ chronic gamma and carbon ion irradiation of Arabidopsis thaliana. Frontiers in Plant Science, 11, 336

Hernandez-Munoz, S., Pedraza-Santos, M. E., Lopez, P. A., Gomez-Sanabria, J. M., \& Morales-Garcia, J. L. (\&\&\&\&). Mutagenesis in the improvement of ornamental plants. Revista Chapingo Serie Horticultura, 25(3), 151-167.

Hlestkina, E. K. (2012). Geny, determiniruyuschie okrasku razlichnyih organoy pshenitsy [Genes determining coloring of various wheat organs]. Vavilov Journal of Genetics and Breeding, 16(1), 202-216 (in Russian).

Jankowicz-Cieslak, J., Tai, T. H., Kumlehn, J., \& Till, B. J. (2017). Biotechnologies for plant mutation breeding. Springer Cham, города.

Jia, Y., Selva, C., Zhang, Y., Li, B., McFawn, L. A., Broughton, S., Zhang, X., Westcott, S., Wang, P., Tan, C., Angessa, T., Xu, Y., Whitford, R., \& Li, C. (2020). Uncovering the evolutionary origin of blue anthocyanins incereal grains. The Plant Journal, 101, 1057-1074.

Jiang, W., Liu, T., Nan, W., Jeewani, D. C., Niu, Y., Li, C., Wang, Y., Shi, X., Wang, C., Wang, J., Li, Y., Gao, X., \& Wang, Z. (2018). Two transcription factors $\mathrm{TaPpm} 1$ and TaPpb1 co-regulate anthocyanin biosynthesis in purple pericarps of wheat. Journal of Experimental Botany, 69(10), 2555-2567.

Khazaei, H., Mäkelä, P. S. A., \& Stoddard, F. L. (2018). Ion beam irradiation mutagenesis in rye (Secale cereale L.), linseed (Linum usitatissimum L.) and faba bean (Vicia faba L.). Agricultural and Food Science, 27, 146-151.

Konopatskaia, I., Vavilova, V., Blinov, A., \& Goncharov, N. P. (2016). Spike morphology genes in wheat species (Triticum L.). Proceedings of the Latvian Academy of Sciences, Section B, 70(6), 345-355.

Krotova, L. A., \& Beletskaya, E. Y. (2015). Vliyanie genotipa i sredyi na kombinatsionnuyu sposobnost' hemomutantov myagkoj pshenitsy po produktivnost rasteniy [Influence of genotype and environment on combining ability of bread wheat chemomutants on plant productivity]. Eurasian Union of Scientists, 19(10), 12-15 (in Russian).

Makeen, K., \& Babu, S. B. (2010). Mutagenic effectiveness and efficiency of gamma rays, sodium azide and their synergistic effects in urd bean (Vigna mungo L.). World Journal of Agricultural Sciences, 2(6), 234-237.

Mir, B. A. S., Maria, M., Muhammad, S., \& Ali, S. M. (2020). Potential of mutation breeding to sustain food security. IntechOpen, London.

Morgun, V. V., \& Rybalka, O. I. (2017). Stratehiia henetychnoho polipshennia zernovykh zlakiv z metoiu zabezpechennia prodovolchooi bezpeky, likuvalnoprofilaktychnoho kharchuvannia ta potreb pererobnooi promyslovosti [Strategy for genetic improvement of cereals in order to ensure food security, therapeutic and preventive nutrition and the needs of the processing industry]. Visnyk of the National Academy of Sciences of Ukraine, 3, 54-64 (in Ukrainian).

Morgun, V. V., \& Yakymchuk, R. A. (2010). Viddaleni henetychni naslidky avariji na Chornobylskij AES [Remote genetic consequences of the accident at Chornobyl' NPP]. Logos, Kyiv (in Ukrainian).

Morgun, V. V., \& Yakymchuk, R. A. (2021). Henetychni naslidky Chomobylskoji katastrofy: 35 rokiv doslidzhen' [Genetic consequences of the Chomobyl disaster: From the experience of 35 years of study]. Plant Physiology and Genetics, 53(3), 216-239 (in Ukrainian).

Morgun, V. V., Yakymchuk, R. A., \& Azizov, I. V. (2019). Peculiarities of the mechanisms of spontaneous and induced by ionizing radiation and chemical factors mutagenesis. Plant Physiology and Genetics, 51(6), 463-481.

Mousseau, T. A., \& Møller, A. P. (2020). Plants in the light of ionizing radiation: what have we learned from Chernobyl', Fukushima, and other "hot" places? Frontiers in Plant Science, 11, 552.

Nazarenko, M. M. (2020). Induction of winter wheat plant structure mutationsby chemomutagenesis. Agrology, 3(2), 57-65.

Nazarenko, M., Lykholat, Y., Grygoryuk, I., \& Khromikh, N. (2018). Optimal doses and concentrations of mutagens for winter wheat breeding purposes. Part I Grain productivity. Journal of Central European Agriculture, 19(1), 194-205.
Oladosu, Y., Rafii, M. Y., Abdullah, N., Hussin, G., Ramli, A., Rahim, H. A., Miah, G., \& Usman, M. (2016). Principle and application of plant mutagenesis in crop improvement: A review. Biotechnology and Biotechnological Equipment, 30(1), 078333.

Olsen, J. E., \& Dineva, S. B. (2017). Effects of chronic ionizing radiation and interactions with other environmental and climatic factors on plant growth and development. eJournal of Applied Forest Ecology, 5(1), 31-53.

Pozolotina, V. N. (2003). Otdalennye posledstvija deystvija radiatsii na rastenija [Longterm effects of radiation on plants]. Akademkniga, Ekaterinburg (in Russian).

Qaim, M. (2020). Role of new plant breeding technologies for food security and sustainable agricultural development. Applied Economic Perspectives and Policy, 42(2), 129-150.

Rasheed, A., Mujeeb-Kazi, A., Ogbonnaya, F. C., He, Z., \& Rajaram, S. (2018). Wheat genetic resources in the post-genomics era: Promise and challenges. Annals of Botany, 121, 603-616.

Ryabchenko, O., \& Nonhebel, S. (2016). Assessing wheat production futures in the Ukraine. Outlook on Agriculture, 45(3), 16664159.

Sanzharova, N. I., \& Fesenko, S. V. (2018). Radioekologicheskie posledstvija avarii na Chernobyilskoj AES: Biologicheskie effekty, migratsija, reabilitatsija zagriaznennykh territorij [Radioecological consequences of the accident at the Chernobyl nuclear power plant: Biological effects, migration, rehabilitation of contaminated areas]. Russian Academy of Sciences, Moscow (in Russian).

Senapati, N., \& Semenov, M. A. (2020). Large genetic yield potential and genetic yield gap estimated for wheat in Europe. Global Food Security, 24, 1003-1040.

Shoeva, O. Y., \& Khlestkina, E. K. (2018). Anthocyanins participate in the protection of wheat seedlings against cadmium stress. Cereal Research Communications, 46(2), 242-252.

Shoeva, O. Y., Gordeeva, E. I., Arbuzova, V. S., \& Khlestkina, E. K. (2017). Anthocyanins participate in protection of wheat seedlings from osmotic stress. Cereal Research Communications, 45(1), 47-56.

Shuryak, I., \& Brenner, D. J. (2021). Quantitative modeling of multigenerational effects of chronic ionizing radiation using targeted and nontargeted effects. Scientifc Reports, 11, 1-11

Sidorov, V. P. (1994). Tsitogeneticheskiy effekt v kletkah hvoi sosny obyknovenno pri obluchenii v rezultate avarii na Chernobyilskoj AES [Cytogenetic effect in the cells of Scots pine needles during irradiation as a result of the Chernobyl accident]. Radiation Biology, Radioecology, 34(6), 847-851 (in Rassian)

Simonov, A. V., Pshenichnikova, T. A., Lapochkina, I. F., \& Watanabe, N. (2017). Interaction of genes determining the spike shape of wheat and those located in the 5AL chromosome. Russian Journal of Genetics: Applied Research, 7, 21-28.

Tadesse, W., Sanchez-Garcia, M., Thabet, A. S., Tawkaz, S., Hanafi, S. E., El-Baouchi, P. S. A., Eddakir, K., El-Shamaa, K., Assefa, S., \& Baum, M. (2019) Wheat breeding handbook at ICARDA. ICARDA, Beirut.

Vavilov, N. I. (1966). Izbrannyie sochineniya (Genetika i selektsiya) [Selected works (Genetics and breeding)]. Kolos, Moscow (in Russian).

Venske, E., Santos, R. S., Busanello, C., Gustafson, P., \& Oliveira, A. C. (2019). Genetic diversity and stability of performance of wheat population varieties developed by participatory breeding. Hereditas, 156, 384 .

Yakymchuk, R. A. (2019). Henetychni naslidky zabrudnennia navkolyshnoho seredovyshcha pryrodnymy i tekhnohennymy mutahennymy chynnykamy [Genetic consequences of the contamination of the environment with natural and technogenic mutagenic factors]. Logos, Kyiv (in Ukrainian).

Yang, G., Luo, W., Zhang, J., Yan, X., Du, Y., Zhou, L., Li, W., Wang, H., Chen, Z., \& Guo, T. (2019). Genome-wide comparisons of mutations induced by carbonion beam and gamma-rays irradiation in rice via resequencing multiple mutants. Frontiers in Plant Science, 10, 1514.

Zaichkina, S. I., Rozanova, O. M., Aptikaeva, G. F., Achmadieva, A. C., \& Klokov, D. Y. (2004). Low doses of gamma-radiation induce nonlinear dose responses in mammalian and plant cells. Nonlinearity in Biology, Toxicology and Medicine, 2, 213-221.

Zaidi, S. S., Vanderschuren, H., Qaim, M., Mahfouz, M. M., Kohli, A., Mansoor, S., \& Tester, M. (2019). New plant breeding technologies for food security. Science, 363, 1390-1391. 